JAMP: Jurnal Adminitrasi dan Manajemen Pendidikan

Volume 4 Nomor 2 Juni 2021, Hal : 139 - 151

Tersedia Online di http://journal2.um.ac.id/index.php/jamp/

ISSN 2615-8574 (online)

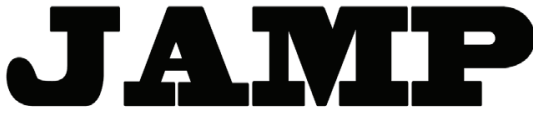

JURNAL ADMINISTRASI DAN MANAJEMEN PENDIDIKAN

\title{
PENGEMBANGAN APLIKASI SISTEM INFORMASI LAYANAN AKADEMIK BERBASIS CODEIGNITER
}

\author{
Mohammad Syahidul Haq \\ Wagino \\ Khofidotur Rofiah \\ Nur Aini D. S \\ Universitas Negeri Surabaya, Suabaya, Indonesia \\ E-mail:mohammadhaq@unesa.ac.id. No. HP 085649799995
}

\begin{abstract}
The development of a management information system is one of the efforts that can be made to improve the quality of public services, both in general and in certain sectors, for example education, especially at times like this (COVID-19 pandemic), where community social activities switch to using assistance. technology. This study aims to develop an existing educational service in the Faculty of Education, State University of Surabaya to facilitate students in accessing all the needs regarding correspondence and is called the Academic Service Information System of the Faculty of Education, Unesa. This research was conducted using the Research and Development (R\&D) method, by applying nine of the ten steps proposed by Borg and Gall. The result of this research is that E - Service Faculty of Education Science is suitable or near perfect for use, with the result of each stage are as follows: (1) in the first testing phase (Preliminary Field Testing), the presentage of yield exceeds $30 \%$ in each category; (2) in the second testing phase, several obstacles were found, but can be resolved in the next stage; (3) in the last testing phase (Operational Product Testing), the presentage of yield exceeds $70 \%$ in each category, this mean that $\mathrm{E}$ - Layanan development is very useful. Also, with the existing of $\mathrm{E}$ - Layanan, academic service activities are greatly helped, especially on this Covid -19 pandemic period.
\end{abstract}

Keywords: Education; Management information system; public services.

Abstrak: Pengembangan sistem informasi manajemen merupakan salah satu upaya yang dapat dilakukan untuk meningkatkan kualitas pelayanan publik, baik secara umum maupun pada sektor - sektor tertentu, misalnya pendidikan, terutama pada saat seperti ini (pandemi covid - 19), di mana kegiatan sosial masyarakat beralih menggunakan bantuan teknologi. Penelitian ini bertujuan untuk mengembangkan suatu layanan pendidikan yang ada di Fakultas Ilmu Pendidikan Universitas Negeri Surabaya untuk memudahkan mahasiswa dalam mengakses segala kebutuhan mengenai surat menyurat dan dinamakan dengan sistem informasi layanan akademik Fakultas Imu Pendidikan Unesa. Penelitian ini dilakukan dengan menggunakan metode Research and Development (R\&D), dengan menerapkan sembilan dari sepuluh langkah yang dikemukakan oleh Borg and Gall. Hasil penelitian ini adalah E - Layanan Fakultas Ilmu Pendidikan sesuai atau mendekati sempurna untuk digunakan, dengan hasil pada masing - masing tahap adalah sebagai berikut: (1) pada tahap pengujian awal (Preliminary Field Testing) mendapatkan presentase hasil melebihi 30\% pada setiap kategorinya; (2) pada tahap pengujian yang kedua ditemukan beberapa hambatan tetapi dapat terselesaikan pada tahap selanjutnya; (3) pada tahap pengujian yang terakhir (Operational Product Testing) mendapat presentase hasil melebihi 70\% pada masing - masing kategorinya, ini berarti bahwa pengembangan E - Layanan sangat berguna. Dengan adanya E - Layanan juga aktivitas layanan akademik sangat terbantu terutama pada pasa pandemi Covid -19 seperti saat ini.

Kata kunci: Pendidikan; Sistem Informasi Management; Layanan Publik. 
Pandemi covid - 19 mulai mewabah di seluruh dunia pada akhir tahun 2019, dimulai dari Cina sebagai negara pertama yang menjadi tempat wabah ini berkembang hingga pada pertengahan Maret 2020 virus covid - 19 ini mulai menyebar di Indonesia. Virus yang telah menyebar ke seluruh negara di dunia ini mempengaruhi sistem kehidupan masyarakat secara signifikan. Berbagai regulasi dan kebijakan baru dibuat dengan tujuan pencegahan penyebaran virus covid - 19. Mulai dari kebijakan Lockdown (Karantina Wilayah) hingga kebijakan social distancing (pembatasan kegiatan sosial) dilakukan seluruh negara di dunia untuk mencegah penyebaran virus covid - 19 ini. Kebijakan - kebijakan pembatasan kegiatan sosial tersebut membuat masyarakat tidak bisa memenuhi kebutuhan sehari - hari menggunakan cara convensional lagi, seperti sebelumnya. Berkenan atau tidak masyarakat harus beradaptasi dengan cara yang baru untuk memperoleh kebutuhan sehari - hari, yaitu beralih dengan memanfaatkan teknologi informasi dan komunikasi, baik hanya sekedar untuk membeli makan hingga untuk mempertahankan sebuah organisasi/lembaga agar mampu terus berjalan.

Pada masa pandemi covid - 19 seperti saat ini pemanfaatan dan pengembangan sistem informasi sangatlah dibutuhkan. Sistem informasi manajemen yang responsif dan berorientasi pada penguna merupakan salah satu aset yang paling penting bagi sebuah organisasi pada masa pandemi covid - 19 seperti saat ini. Dengan adanya sistem yang baik diharapkan nantinya produktifitas dapat meningkat, jumlah persediaan yang harus dikelola dapat menurun, kegiatan yang tidak memberikan nilai tambah dapat dikurangi, pelayanan kepada pelanggan juga dapat meningkat, dan dapat mempermudah pengambilan keputusan oleh sebuah organisasi, serta dapat mempermudah manajemen untuk mengkoordinasikan kegiatan dalam organisasi, sehingga keefektifan dan efisiensi dapat terwujud pada sebuah organisai atau lembaga.

Pengguna internet mengalami kenaikan yang signifikan pada tahun 2020. Survei yang dilakukan oleh Asosiasi Penyelenggara Jasa Internet Indonesia (APJII) pada 2 sampai 5 juni 2020 menunjukkan hasil bahwa pengguna internet di Indonesia meningkat dari 171, 2 juta jiwa pada 2018 menjadi 196, 7 juta jiwa pada 2020. Ketua Umum APJII Jamalul Izza menyebutkan, bahwa faktor yang mempengaruhi peningkatan tersebut salah satunya adalah kondisi saat ini (Pandemi covid - 19), dimana masyarakat harus online untuk melakukan kegiatan sehari - hari. (KOMPAS.COM, (09/11/2020)). Peningkatan tersebut berarti bahwa pengguna sistem informasi juga meningkat, inilah mengapa dibutuhkan pengembangan sistem informasi manajemen, terlebih pada masa pandemi covid - 19, dimana semua aktivitas masyarakat dilakukan dengan bantuan teknologi informasi dan komunikasi atau secara online, termasuk juga dengan pendidikan.

Pengebangan sistem informasi manajemen juga perlu diterapkan dalam lembaga pendidikan karena dalam menghadapi persaingan global lembaga pendidikan dituntut untuk memberikan informasi lebih cepat, akurat dan nyaman yang merupakan bagian dari kualitas pelayanan, sehingga akan menjadi sebuah keunggulan bersaing (competitive advantage), dan juga karena untutan kebutuhan yang semakin kompleks dan serba percepatan menyebabkan adanya perubahan dan perlunya teknologi dalam lembaga pendidikan, terlebih pada masa pandemi covid - 19 seperti saat ini dimana pemerintah menerapka kebijakan work from home dan pendidikan jarak jauh (online). Pengembangan sistem informasi manajemen perlu diterapkan pada lembaga pendidikan dengan didasarkan pada asas peningkatan efisiensi dan kualitas pelayanan publik. Salah satu tujuan penerapan sistem informasi manajemen pada lembaga pendidikan adalah untuk mendukung kegiatan fungsi manajemen yaitu perencanaan, pengorganisasian, kepegawaian, pembinaan, evaluasi, koordinasi dan penganggaran untuk mendukung terwujudnya maksud dan tujuan fungsi operasional organisasi pendidikan.

Adanya sistem informasi manajemen lembaga pendidikan akan merasakan beberapa manfaat sebagai berikut, pertama, tersedianya sistem pengelolaan data dan informasi pendidikan. Data adalah fakta-fakta dan gambar mentah yang akan di proses menjadi informasi (Williams dan Sawyer, 2007:39). Connolly dan Begg (2010:70), mendefinisikan, dari sudut pandang end-user, data merupakan bagian terpenting dalam database management system (DBMS). Data berfungsi sebagai penghubung antara mesin dengan pengguna. Hal ini berarti dengan memanfaatkan sistem informasi manajemen dengan baik maka lembaga pendidikan akan memiliki data - data terkait pendidikan dan dapat mengelolanya menjadi informasi yang sesuai dengan yang ingin disampaikan kepada pengguna (user). DAPODIK 
adalah sebuah sistem pendataan dan pengelolaan data - data yang bersifat makro secara online dan real time. Dapodik berfungsi untuk menyediakan basis data yang bekerja secara terus - menerus, sehingga dapat menciptakan pengelolaan data yang representativ untuk memenuhi kebutuhan kementrian dan pemangku kepentingan pendidikan lainnya. Tujuan lainnya yaitu untuk meningkatkan kualitas sinergi kegiatan pengumpulan data pokok yang terintegrasi dalam satu sistem pendataan secara efektif dan efisien. Pernyataan ini sesuai dengan hasil penelitian yang dilakukan oleh (Ahmad La Ode dan Sinan, 2017), yaitu "sistem informasi manajemen penting untuk diterapkan pada lembaga pendidikan, misalnya seperti penggunaan aplikasi pengolah data yaitu dapodik dan teknologi informasi dalam mendukug proses pembelajaran dapat meningkatkan layanan pendidikan dengan cara menfasilitasi praktek pembelajaran dengan memanfaatkan teknologi informasi dan komunikasi, seperti media belajar yang menggunakan bantuan komputer". Selanjutnya penelitian yang dilakukan oleh (Gushchin dan Ochepovsky, 2019) juga menunjukkan hasil yang relevan, yaitu "memiliki banyak informasi yang diperoleh melalui proses manajemen risiko e-learning dan menggunakannya dalam data mining, memungkinkan untuk menentukan alasan dan tindakan yang diambil lebih bergantung pada minimalisasi risiko dan memperkuat efektivitas e-learning". Maka dapat disimpulkan bahwa sistem informasi manajemen sangat bermanfaat untuk pengelolaan data dan informasi pendidikan.

Kedua, terintegrasinya data dan informasi pendidikan untuk mendukung proses pengambilan keputusan. James (2009) menjelaskan pengambilan keputusan merupakan serangakain proses yang dilakukan guna memecahkan suatu masalah dengan melihat dari beberapa alternatif pemecahan masalah yang ada. Sistem dapat digunakan oleh para manjer untuk membantu mereka dalam kegiatan pengambilan keputusan dengan cara mengamati lingkungan dalam organisasi. Misalnya seperti, Link Elektronik di sekolah Tunas Bangsa, yang digunakan untuk mengamati jumlah pendapatan atau pendaftaran siswa baru setiap tahun. Hal ini juga berarti bahwa dengan menggunakan sistem informasi manajemen berbasis komputer tujuan akan mampu dicapai dengan lebih efektif. Penelitian yang dilakuakan oleh (Yuniko dan Putra, 2017) juga memaparkan hasil yang relevan, yaitu "Adanya Sistem Informasi Website Dinamis pada Dinas Kependudukan dan Pencatatan Sipil Kabupaten Dharmasraya sebagai media informasi, informasi dari pihak Dinas Kependudukan dan Pencatatan Sipil Kabupaten Dharmasraya dapat lebih cepat tersampaikan kepada masyarakat". Hasil penelitian yang relevan selanjutnya juga dipaparkan pada penelitian yang dilakukan oleh (Aldarbesti dan Saxena, 2014) yaitu "EMIS (Educational Management Information System) harus menggunakan Internet, Intranet serta Extranet untuk mentransfer informasi dengan sangat cepat dan membuat proses pengambilan keputusan sangat cepat. Informasi harus tersedia saat dibutuhkan untuk pengambilan keputusan". Ini berarti bahwa sistem informasi manajemen sangatlah penting untuk menunjang pengambilan keputusan dengan cepat dan tepat.

Ketiga, tersedianya data dan informasi pendidikan yang lengkap bagi seluruh stakholders yang berkepentingan dalam bidang pendidikan. Sistem informasi manajemen juga juga dapat memberikan kepuasan kepada penggunanya (user satisfaction). Data dan informasi yang lengkap akan memberikan manfaat bagi stakeholder, misalnya manajer fungsional diberitahu tentang kemajuan, pencapaian dan kekurangan dalam kegiatan dan target. Manajer tetap waspada dengan memberikan informasi tertentu yang menunjukkan dan kemungkinan tren dalam berbagai aspek bisnis. Ini membantu dalam peramalan dan perencanaan perspektif jangka panjang. Perhatian manajer diarahkan pada situasi yang diharapkan di alam, mendorongnya untuk mengambil tindakan atau keputusan dalam masalah tersebut (Bright dan Asare, 2019). Penelitian yang dilakukan oleh (Bright dan Asare, 2019) juga memaparkan hasil yang relevan, yaitu "studi ini merekomendasikan keterkaitan yang efektif dari semua sistem informasi untuk meningkatkan penggunaannya untuk kepentingan semua pemangku kepentingan." Dengan tersedianya data dan informasi yang lengkap untuk kepenringan stakeholder, maka tujuan juga akan tercapai dengan lebih efektif. Hasil penelitian yang relevan selanjutnya juga dipaparkan pada penelitian yang dilakukan oleh (Apriyansyah, Maullidina, Purnomo, 2018) yaitu "Sistem Informasi Desa (SID) yang digunakan oleh Pemerintah Desa Dlingo sudah efektif, cepat dan tepat".

Pemerintah, dalam Inpres No. 11 menyatakan bahwa, sebagai bentuk dukungan pemerintah terhadap perubahan tersebut ke arah yang lebih maju, dengan bentuk kebijakan terkait teknologi informasi Indonesia. Pernyataan 06/2001 tentang pengembangan dan pemanfaatan telematika 
(telekomunikasi, media, dan informatika) di Indonesia pada tanggal 24 April 2001 menyebutkan bahwa, pejabat pemerintah diharuskan untuk menggunakan teknologi telematika sebagai bentuk dukungan menuju tata pemerintahan yang lebih baik dan untuk mempercepat kemajuan demokrasi. Selain itu, "Instruksi Presiden" tentang pengembangan kebijakan e-government dan strategi nasional pada 3 Maret 2003 menunjukkan bahwa e-government adalah mengembangkan e-govermance dan secara efektif dan efisien meningkatkan kualitas pelayanan publik. Kerja keras.

Adanya kebijakan pemerintah di atas diharapkan dapat memajukan negara Indonesia dalam menghadapi persaingan global dan menuhi tuntutan masyarakat modern yang mengharuskan pemerintah memberikan respon yang cepat dan tanggap terhadap berbagai permintaan atau kebutuhan masyarakat, khususnya pada masa pandemi covd -19 seperti sekarang ini.

Sistem Informasi Manejemen (selanjutnya disebut SIM) merupakan kegiatan manajemen yang dilakukan dengan memanfaatkan sistem informasi dalam penerapannya pada sebuah organisasi yang ditujukan untuk memberikan informasi - informasi yang diperlukan oleh organisasi tersebut. Gordon B. Davis, (1993) menjelaskan, SIM merupakan sebuah sistem yang terdiri dari manusia atau mesin yang mampu menyediakan informasi untuk mendukung kegiatan manajerial dan fungsi pengambilan keputusan pada sebuah organisasi. Selain itu, Gordon B. Davis (Gordon B. Davis, 1993) juga menekankan bahwa SIM selalu berkaitan dengan pemrosesan informasi berbasis komputer. SIM adalah sistem yang menjalankan fungsi untuk menyediakan semua informasi yang mempengaruhi operasi semua organisasi.

Sistem informasi manajemen sekarang tidak hanya digunakan untuk kepentingan internal sebuah organisasi saja, misalnya seperti untuk pengambilan keputusan, tetapi saat ini sistem informasi manajemen juga telah digunakan untuk pelayanan publik. Seperti adanya $e$-goverment merupakan bentuk sistem informasi manajemen yang digunakan untuk pelayanan publik pada sektor pemerintahan. Pelayanan publik adalah tanggung jawab pemerintah kepada warga negara. UUD 1945 menetapkan tanggung jawab tersebut, dan tujuan penyelenggaraan pelayanan publik adalah untuk memenuhi kebutuhan hak dasar setiap warga negara dan penduduk atas barang, jasa dan / atau jasa administrasi yang berkaitan dengan kepentingan umum yang disediakan oleh pemerintah. Di era desentralisasi dan demokratisasi saat ini, tuntutan tanggung jawab pelayanan publik semakin kuat dan menonjol (Yuniko dan Putra, 2017:13). Sektor pendidikan saat ini juga telah memanfaatkan sistem informansi manajemen untuk memberikan pelayanan kepada publik, misalnya dengan adanya website suatu lembaga pendidikan, hal tersebut berarti bahwa lembaga pendidikan tersebut telah memberikan pelayanan publik yang berbasis teknologi informasi dan komunikasi.

Berdasarkan beberapa alasan diatas dan berkaitan dengan pelayanan publik yang berbasis teknologi informasi, peneliti mencoba mengembangkan suatu layanan pendidikan yang ada di Fakultas Ilmu Pendidikan Universitas Negeri Surabaya untuk memudahkan mahasiswa dalam mengakses segala kebutuhan mengenai surat menyurat meliputi: surat pengunduran diri, surat mutasi kuliah, surat cuti kuliah, formulir dan undangan skripsi, surat ijin penelitian, surat ijin observasi, surat pengantar perpus, surat pernyataan kuliah, surat keterangan kuliah, surat unggah artikel yang berbasis online dan dinamakan dengan sistem informasi layanan akademik Fakultas Imu Pendidikan Unesa.

\section{METODE}

Penelitian ini menggunakan metode Research and Development (R\&D) atau penelitian dan pengembangan. Borg \& Gall (2003), dalam bukunya "Educational Research", menjelaskan bahwa "Research and Development $(R \& D)$ atau penelitian dan pengembangan" dalam pendidikan merupakan model pengembangan industrial yang bertujuan untuk merancang dan mengembangkan produk dimana hasilnya akan digunakan untuk pembelajaran. Hasil rancangan produk pembelajaran tersebut kemudian diuji cobakan di lapangan, dievaluasi, dan disempurnakan hingga dapat menghasilkan produk pembelajaran yang sesuai dengan standar, dan efektif, efisien dan berkualitas untuk digunakan. Diantara bermacam - macam model "Research and Development $(R \& D)$ atau penelitian dan pengembangan" yang ada, model yang dikemukakan oleh Borg dan Gall merupakan model yang secara spesifik mengarahkan penelitian dan pengembangan pada bidang pendidikan, khususnya pembelajaran. Model 
yang dikemukakan oleh Borg dan Gall ini lebih sering dikenal dengan nama model sepuluh langkah. Kesepuluh langkah utama "Research and Development ( $R \& D)$ atau penelitian dan pengembangan" yang dikemukan oleh Borg \& Gall (1983) adalah sebagai berikut:

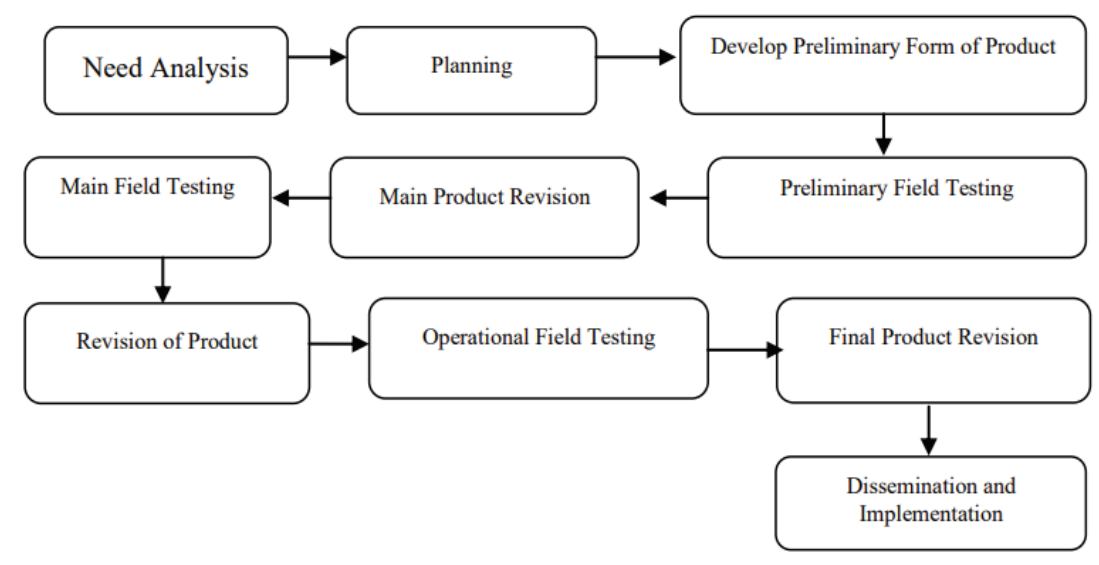

Gambar 4.1 Rancangan Penelitian R \& D

Penelitian ini menggunakan metode Research and Development dengan megembangkan model sistem informasi Layanan Akademik di Fakultas Ilmu Pendidikan Universitas Negeri Surabaya, penelitian ini dibatasi hingga tahap ke sembilan saja yang meliputi tahap analisis kebutuhan, perencanaan, pengembangan model, uji coba produk terbatas, penyempurnaan produk awal, uji coba lapangan lebih luas, penyesuaian produk hasil uji coba lapangan, uji coba produk akhir, dan revisi produk akhir.

\section{HASIL DAN PEMBAHASAN}

Pengembangan e-layanan merupakan salah satu bagian dari penerapan sistem informasi manajemen (SIM) di lembaga pendidikan tinggi. Umumnya, apabila kita menyinggung mengenai Sistem Informasi Manajemen (SIM) yang pertama terbesit adalah teknologi (komputer) yang dimanfaatkan oleh sebuah organisasi untuk mengelola data, seperti yang dipaparkan oleh Aldarbesti dan Saxena, (2014), "Sistem Informasi Manajemen adalah sistem yang berbasis komputer". Pemanfaatan yang dimaksud di sini antara lain yaitu, membantu dalam pengerjaan tugas - tugas rutin, melakukan evaluasi, dan memudahkan dalam melakukan pengambilan keputusan, juga kegiatan manajemen yang bersifat konvensional, seperti pencatatan agenda, kearsipan, dsb (Sutabri, 2005:89). Schrounderberg (Fatta, 2007:3) menjelaskan secara sderhana bahwa sistem merupakan rangkaian komponen sistem yang saling terhubung satu sama lainnya dengan beberapa kriteria. Berikut pembahasan mengenai kriteria sistem informasi manajemen yang dikemukakan oleh Schrounderberg dengan kegiatan pengembangan e-layanan di Fakultas Ilmu Pendidikan Universitas Negeri Surabaya.

1. Suatu keseluruhan tanpa memisahkan komponen pembentuknya.

Pengembangan e-layanan di Fakultas Ilmu Pendidikan terbentuk dari berbagai komponen yaitu mulai dari sarana prasarana, internet, website, pihak pengelola, dosen, dan juga mahasiswa. Komponen tersebut merupakan input, process, dan output dari e-layanan yang merupakan suatu sistem berbasis elektronik.

2. Bersama-sama dalam mencapai tujuan.

E-layanan yang dikembangkan di Fakultas Ilmu Pendidikan Universitas Negeri Surabaya ini memiliki tujuan yaitu untuk meningkatkan efisiensi dan efektivitas sistem informasi manajemen sehingga pihak fakultas dapat memberikan layanan yang maksimal terhadap pelanggan atau mahasiswa.

3. Terdapat aturan terikat.

Pengembangan e-layanan disesuaikan dengan kebutuhan lembaga dalam mengelola dan memberikan pelayanan terhadap mahasiswa. Sehingga dalam implementasi aplikasi atau produk di lapangan harus 
sesuai dengan aturan yang diberlakukan oleh pihak universitas, fakultas, hingga program studi atau jurusan yang ada di Fakultas Ilmu Pendidikan.

\section{Hasil Tahapan Pengembangan Model}

1. Analisis Kebutuhan (Need Analysis).

Pada tahap analisis kebutuhan ini peneliti melakukan pengumpulan data awal dan analisis kebutuhan penelitian. Pengumpulan data awal dilakukan untuk memperoleh informasi yang dapat digunakan untuk mempermudah pelaksanaan penelitian serta resiko apa yang munkin akan terjadi dalam proses. Resiko harus dijelaskan dengan serinci mungkin pada tahap identifikasi ini. Format deskriptif berfungsi untuk menjelaskan dengan serinci mungkin dari setiap resiko yang mungkin akan terjadi, sehingga mampu mendukung secara efektif tahap analisis kebutuhan dan perencanaan (Gushchina dan Ochepovsky, 2019:185). Analisis kebutuhan pada penelitian ini dilakukan menggunakan dua metode, yaitu observasi dan wawancara (interview) oleh pengguna Layanan Akademik meliputi mahasiswa, tenaga administrasi dan pimpinan Fakultas. Terkait kebutuhan baik pengguna maupun kebijakan fakultas. Disamping itu peneliti juga mengidentifikasi sarana dan prasaran yang ada pada Fakultas Ilmu pendidikan baik dari segi software, hardware, dan jaringan internet. Sumber daya manusia juga tidak lepas dari identifikasi peniliti sebagai pengguna aplikasi nantinya.

\section{Tahap Perencanaan (Planning).}

Tahap kedua yang harus dilakukan oleh peneliti adalah tahap perencanaan. Pada tahap perencanaan ini, peneliti merencanakan secara detail dari produk yang akan dikembangkan berdasarkan dari hasil analisis kebutuhan yang telah dilakukan. Beberapa hal yang harus dilakukan mencakup, menentukan tujuan pembuatan poduk, aspek Layanan Akademik yang akan dikembangkan, menentukan prosedur pembuatan produk, dan mengurus perizinan penelitian, dan yang terakhir adalah membuat rancangan konsep dasar dari produk yang akan dikembangkan. Tentunya berdasarkan hasil identifikasi pada tahap sebelumnya yang tujuan utamanya adalah mempercepat pengembangan layanan akademik.

\section{Tahap Pengembangan Produk Awal (Develop Preliminary of Product).}

Setelah pada tahap sebelumnya peneliti telah menentukan aspek produk yang akan dikembangkan, pada tahap ini peneliti melakukan pengemabangan rencana atau desain dasar konsep yang telah dibuat pada tahap sebelumnya, diantaranya yang harus dilakukan adalah yang pertama yaitu, membuat rancangan grafis, menyusun rekayasa source code, dan membuat desain layout halaman muka website. Dalam proses pengembangan peneliti menggunakan beberapa software untuk mendukung pembuatan aplikasi. Software yang digunakan antara lain: Corel Draw : Digunakan untuk desain aplikasi dari segi grafis, Xampp : Aplikasi yang digunakan untuk Server Lokal, Codeigniter : Merupakan FrameWork yang biasa digunakan dalam coding sebuah aplikasi berbasis website, Google Crome : Aplikasi yang digunakan untuk membuka halaman Aplikasi Layanan Akademik

Berikut ini tampilan utama dari Aplikasi Layanan Fakultas Ilmu Pendidikan

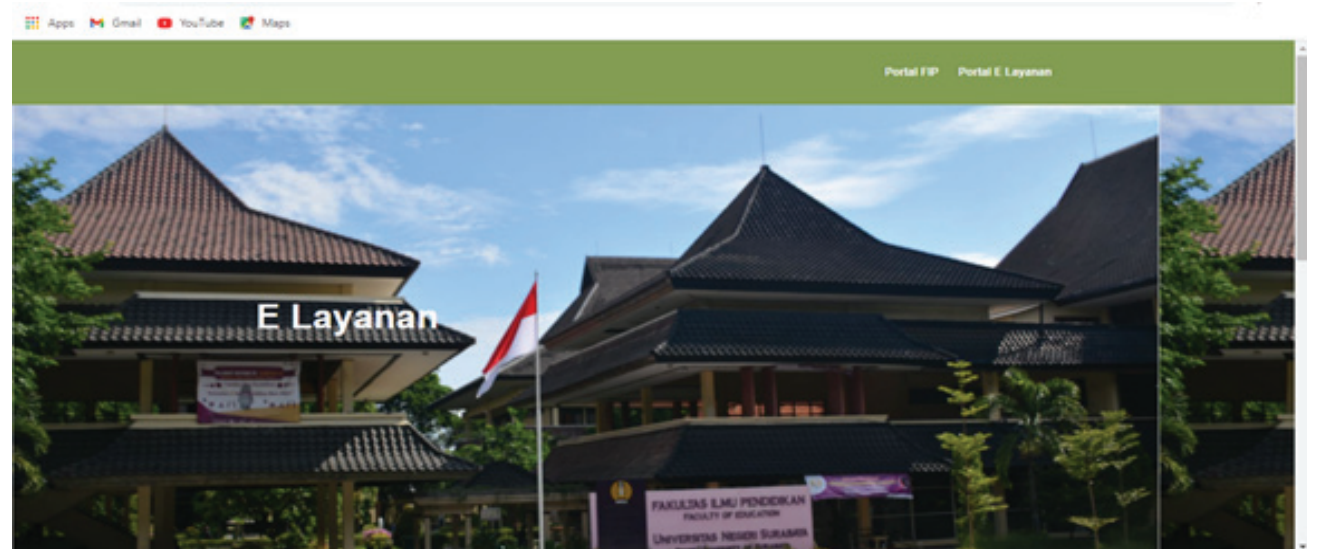




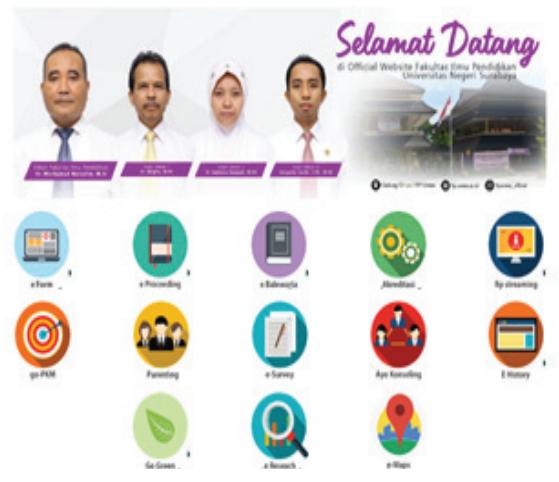

Dalam aplikasi E Layanan terdapat beberapa pilihan menu yang berfungsi untuk memudahkan penggunanya. Berikut ini diskripsi dari menu menu yang berada pada aplikasi e layanan Fakultas Ilmu Pendidikan.

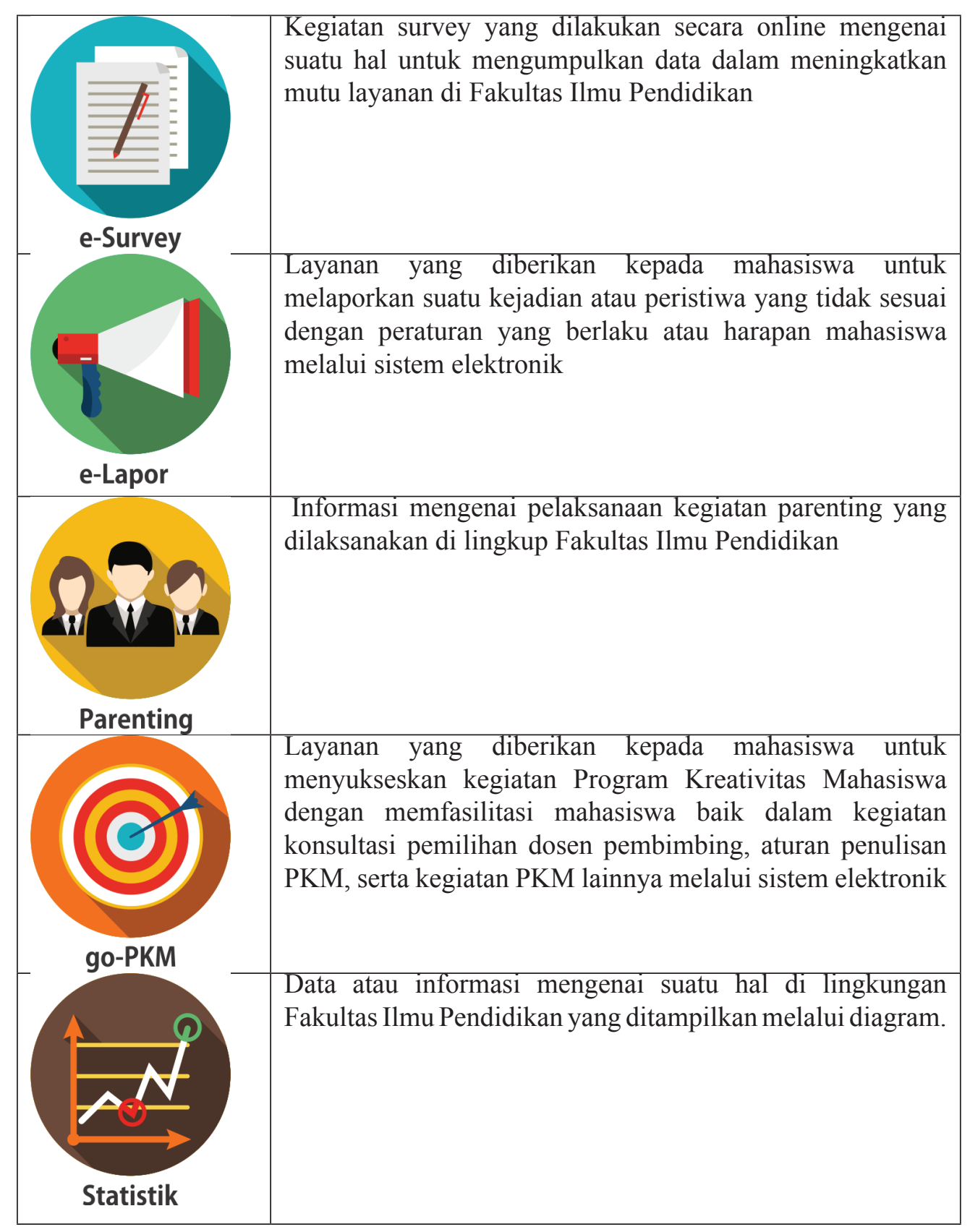




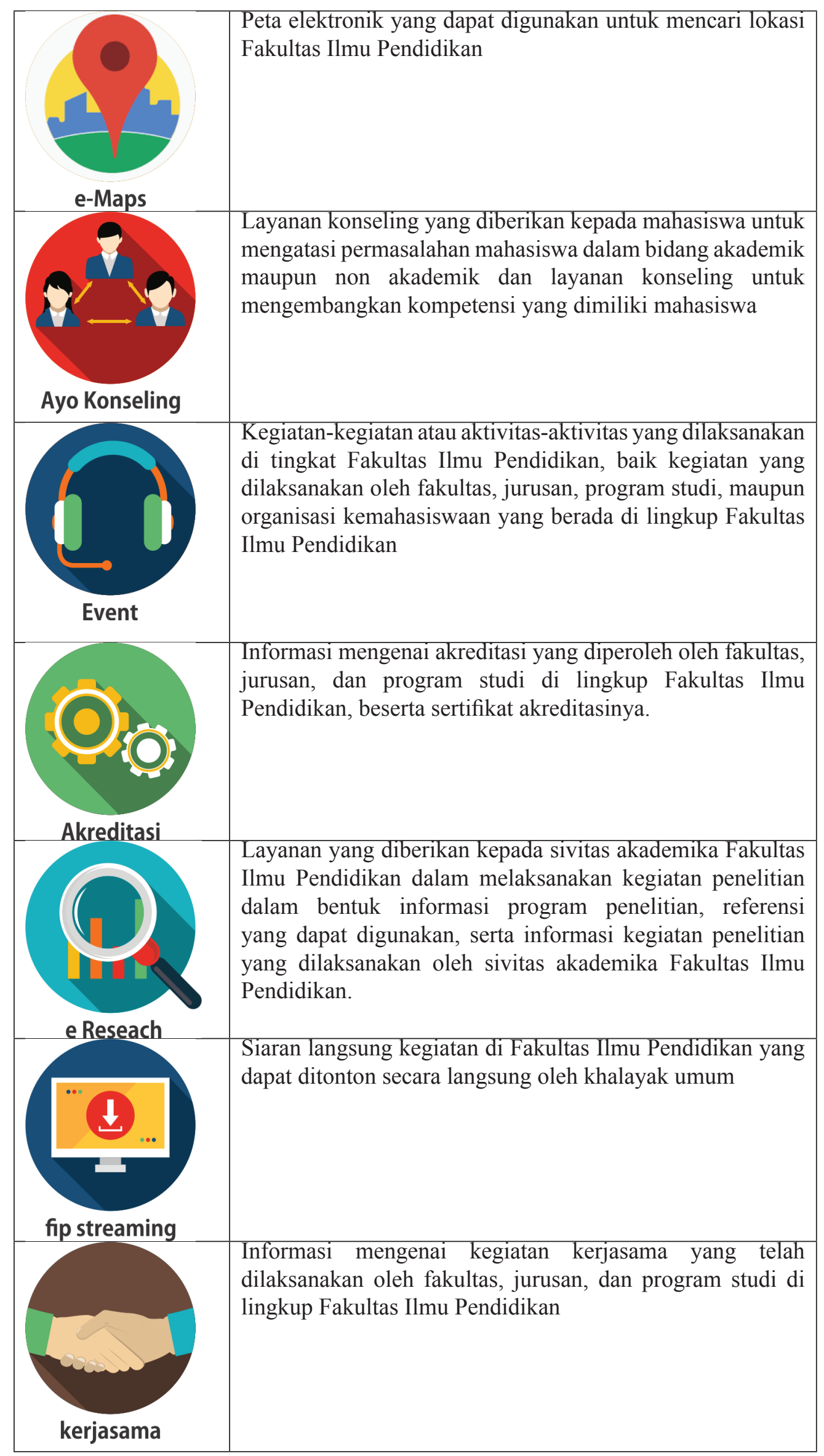




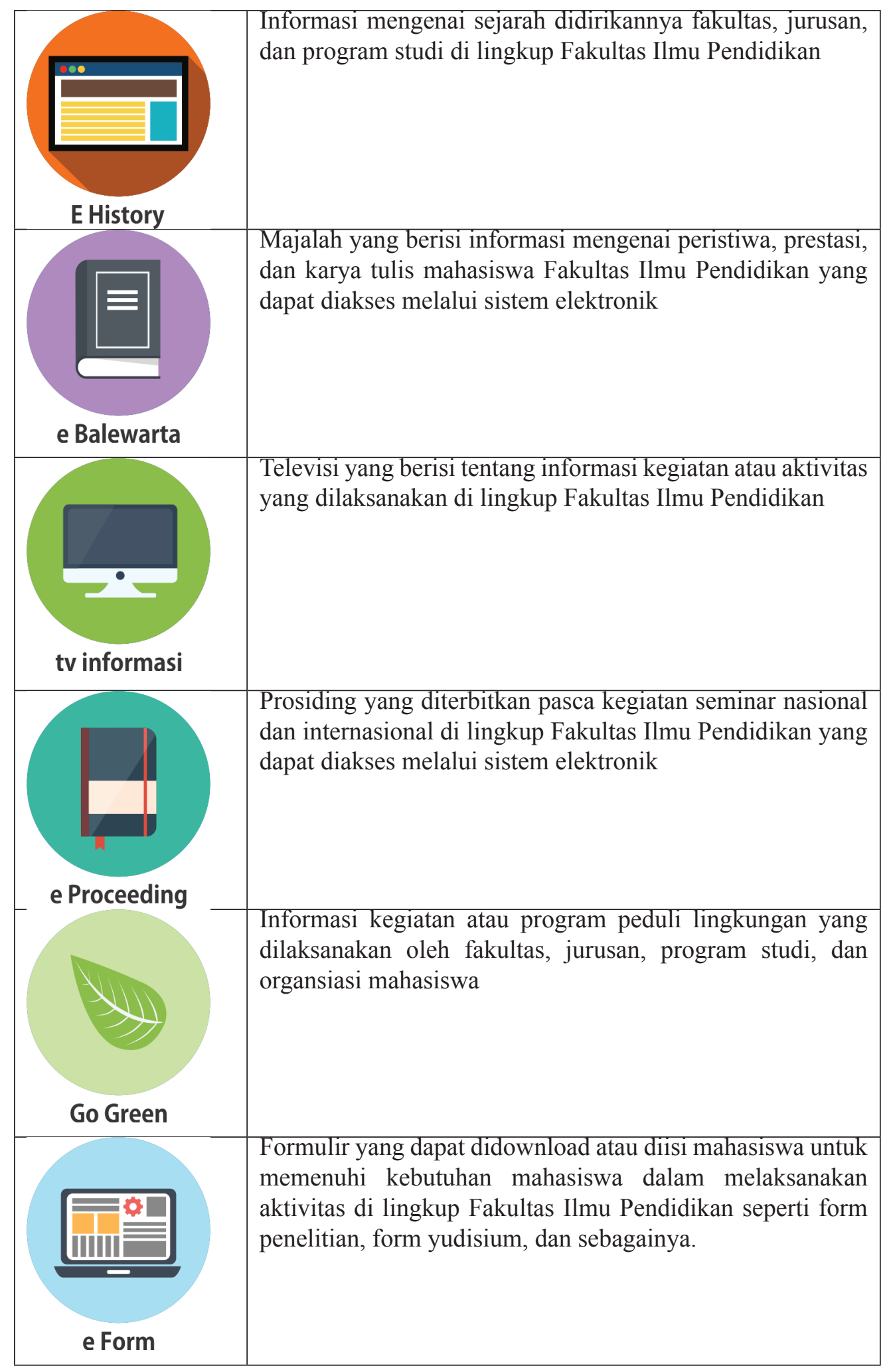

4. Uji Coba Pengguna (Preliminary Field Testing).

Setelah desain produk telah dibuat, tahap selanjutnya yang harus dilakukan oleh peneliti yaitu menguji coba produk tersebut. Tahap ke-empat ini bertujuan untuk melakukan pengujian awal terhadap desain produk yang telah dibuat. Pengujian awal ini bersifat terbatas, bertujuan hanya untuk menguji apakah program aplikasi yang telah dibuat dapat berjalan dengan baik dan lancar. Dalam Ujicoba terbatas bagi pengguna peneliti mengambil sampel 5 orang yang kedepan sebagai pengguna aplikasi ini. 
Dalam ujicoba terbatas dilakukan melalui Laman http://localhost/elayanan diperoleh hasil dari beberapa indikator sebgai berikut:
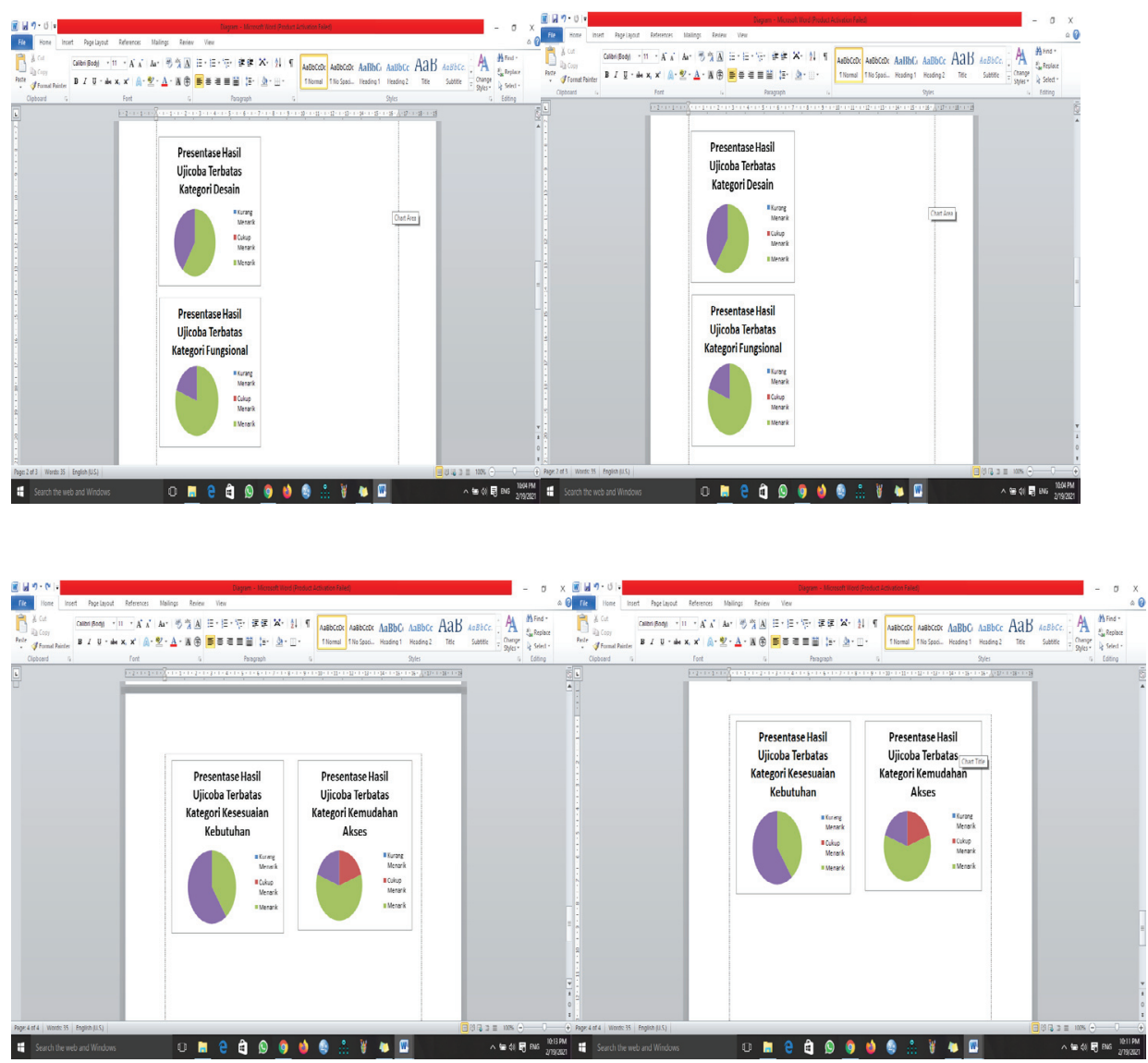

5. Revisi Hasil Uji Coba Pengguna (Main Product Revision).

Setelah produk diuji coba secara terbatas, langkah sselanjutnya yang harus dilakukan oleh peneliti yaitu merevisi atau memperbaiki kelemahan atau kekurangan produk yang ditemukan pada saat uji coba terbatas. Hasil dari uji coba terbatas menunjukkan bahwa produk masih perlu perbaikan pada pendeskripsian produk, maka dari itu pada tahap ini perbaikan lebih banyak dilakukan menggunakan pendekatan kualitatif produk, dengan tujuan untuk memberikan pendeskripsian lebih baik mengenai item - item yang ada pada produk.

\section{Uji Coba Ahli (Main Field Testing).}

Tahap selanjutnya yang harus dilakukan oleh peneliti setelah melakukan perbaikan produk yaitu melakukan pengujian produk secara lebih luas. Tahap ini dilakukan dengan tujuan untuk melihat sejauh mana efektivitas dari desain produk yang telah dibuat. Hasil dari uji coba apangan ini nantinya akan dikumpulkan, dan kemudian akan diobservasi dengan tujuan untuk melihat tingkat keefektifan dan efisiensi dari produk tersebut. Aplikasi E-Layanan yang dikembangkan divalidasi terlebih dahulu oleh ahli materi dan ahli media. Validasi materi akan dilakukan oleh dosen Manajemen Pendidikan, Fakultas Ilmu Pendidikan Universitas Negeri Surabaya yang memiliki latar belakang sesuai dengan materi yang dikembangkan. Validasi ini bertujuan untuk memperoleh informasi, kritik serta saran agar aplikasi E-Layanan yang dikembangkan menjadi produk yang berkualitas. Sedangkan untuk ahli media dilakukan untuk mendapatkan masukan terkait desain, tampilan, kecepatan akses terkait aplikasi yang telah dikembangkan.

\section{Revisi Hasil Ahli (Operational Product Revision).}

Setelah produk diuji coba untuk yang kedua kalinya, pada tahap ini produk akan diperbaiki kembali. Tujuan dari perbaikan produk pada tahap ini adalah untuk menyempurnakan produk sehingga dapat menjadi lebih baik lagi. Berdasarkan kegiatan uji coba yang dilaksanakan melalui subjek uji coba ada 
dua hambatan mendasar yang ditemukan dalam pengembangan sistem e-layanan berbasis website ini.

Hambatan pertama yang muncul yaitu bahwa ada beberapa link yang belum tersambung dengan website. Seperti yang kita ketahui bahwa e-layanan ini dikembangkan melalui berbagai aplikasi mulai dari e-Survey hingga FIP Streaming yang bisa diakses melalui link yang dibagikan ole pihak pengelola. Akan tetapi ada beberapa link yang belum tersambung dengan website.Solusi yang dilakukan dalam permasalahan ini adalah dengan memperbaiki sistem website dengan mengkomunikasinnya dengan tenaga ahli sehingga dapat teratasi dengan baik dan dapat diakses dengan mudah.

Kedua yaitu tampilan aplikasi di website yang terlalu kecil. Tampilan website merupakan bagian penting dalam pengembangan e-layanan ini. Tampilan menentukan penilaian pengguna terhadap aplikasi/website. Dari tampilan kita bisa menilai apakah websitenya menarik, membantu, atau malah mempersulit. Berdasarkan hasil uji coba oleh ahli yaitu Syunu Trihantoyo, M.Pd., dan Fajar Ariyanto, M.Pd. mengemukakan bahwa tampilan website terlalu kecil sehingga kurang efektif dan kadang mempersulit pengguna. Maka dari itu, peneliti sudah memperbaikinya dengan memperbesar tampilan menu-menu di website sehingga dapat dengan diakses dengan tampilan baru.

\section{Uji Coba Produk Akhir (Operational Product Testing).}

Tahap ini merupakan tahap uji coba yang terakhir, dengan lebih banyak sampel yang digunakan. Hasil penyempurnaan produk pada tahap sebelumnya akan diterapkan pada tahap ini. Hasil ujicoba produk akhir penelitian ini adalah sebagai berikut:

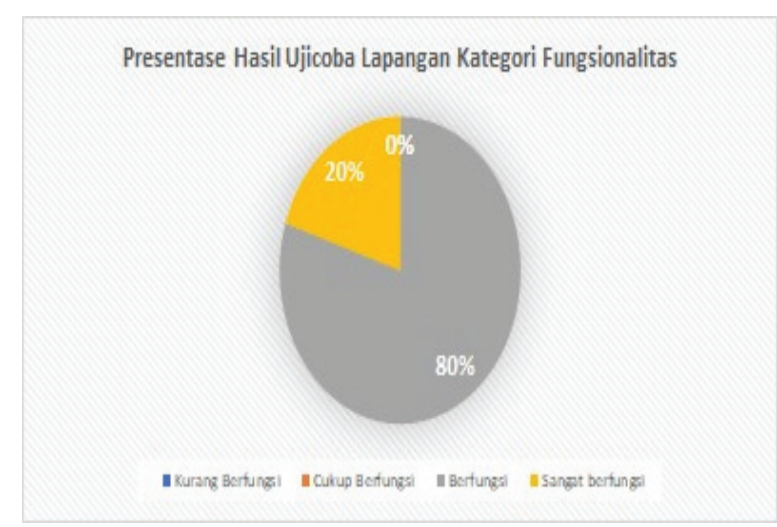

Presentase Hasil Ujicoba Lapangan Kemudahan Akses

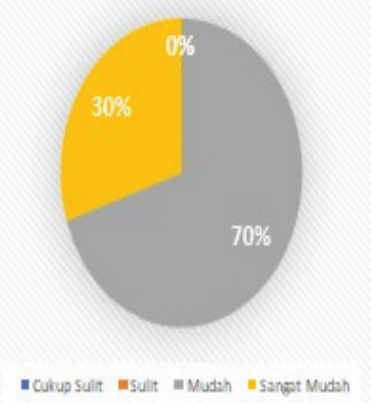

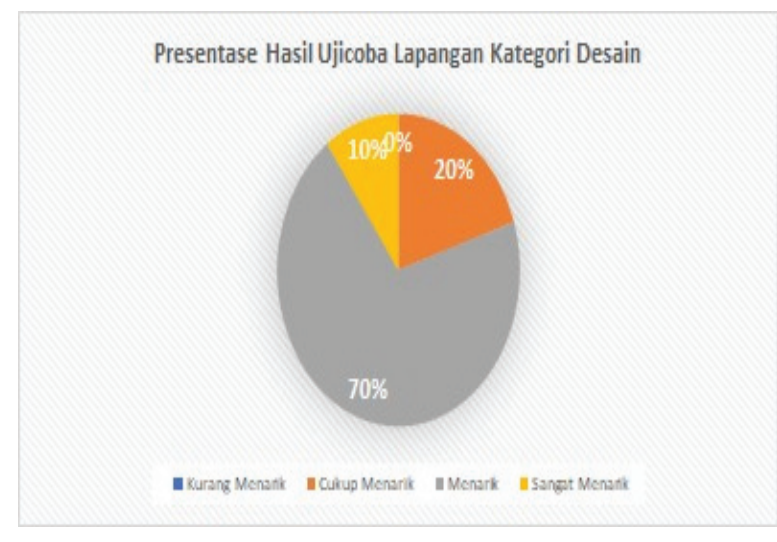

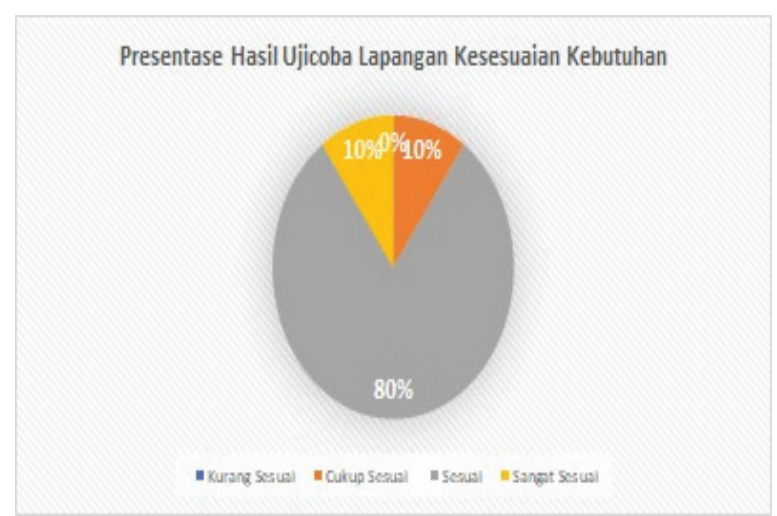

9. Revisi Produk Akhir (Final Product Revision).

Tahap inin merupakan tahap penyempurnaan produk yang terakhir kalinya sebelum produk diimplementasikan pada lingkungan. Tahap penyempurnaan produk yang terakhir ini ini dipandang sangat diperlukan guna mengukur keakuratan produk yang dikembangkan. Pada tahap ini nantinya dihapkan dapat menghasilkan produk yang memiliki tingkat keefektifan yang dapat dipertanggung jawabkan. Revisi produk dilakukan berdasarkan masukan dari Ahli media, ahli materi dan pengguna aplikasi. Setelah dilakukan revisi produk selanjutnya aplikasi dipublikasikan melalui laman http://layanan. fip.unesa.ac.id agar semua civitas akademika Fakultas Ilmu Pendidikan dapat memanfaatkan fasilitas E-Layanan. Dengan adanya aplikasi e-layanan aktifitas layanan akademik sangat terbantu apalagi dalam 
kondisi pandemi covid-19. Segala bentuk layanan akademik dapat dilakukan secara online tanpa terbatas ruang dan waktu kapan saja dan dimana saja.

\section{Kelebihan dan Kekurangan E-Layanan}

Keberhasilan dari penyelenggaraan pendidikan salah satunya dapat dilihat dari kualitas pelayanan yang diberikan oleh lebaga pendidikan kepada pengguna jasa pendidikan, seperti siswa, stakeholder, dan masyarakat, atau sederhananya layanan pendidikan dapat diartikan juga sebagai jasa pendidikan yang diberikan oleh lembaga pendidikan kepada pengguna jasa pendidikan. E-layanan merupakan salah satu pengembangan layanan pendidikan yang berbasis website. E-layanan sekarang ini sudah hampir diterapkan oleh semua lembaga pendidikan baik dari tingkat pendidikan dasar, menengah hingga perguruan tinggi.

Setiap implementasi suatu produk pasti ada kelebihan dan kekurangannya. Begitupun dalam pengembangan layanan pendidikan yang berbasis website ini. Kelebihan dan kekurangan yang dimiliki oleh e-layanan ini nantinya dapat sebagai bahan evaluasi terkait keberlanutan pengembangan produk di masa depan. Adapaun kelebihan yang dimiliki oleh e-layanan yaitu sebagai berikut.

1. Website yang mudah diakses oleh mahasiswa dan dosen.

2. Dapat diakses dimanapun dan kapanpun.

3. Pihak pengelola dapat dengan mudah melayani kebutuhan mahasiswa dan dosen karena suda tersistem dengan baik.

4. Komunikasi antara mahasiswa dengan pihak lembaga atau fakultas bisa terjalin lebih eektif.

5. Mengurangi bentuk penggunaan benda fisik seperti kertas, dll.

6. Selanjutnya untuk kelemahan yang dimiliki oleh e-layanan yaitu sebagai berikut.

7. Bergantung pada provider internet atau wifi.

8. Karena kemudahannya diakses maka sering disalahgunakan untuk hal-hal yang tidak penting.

9. Harus ada pengelola yang siaga 24 jam

10. Mahasiswa dan dosen banyak yang belum menggunakan e-layanan secara maksimal.

\section{SIMPULAN DAN SARAN}

\section{Simpulan}

Sistem Informasi Manejemen (selanjutnya disebut SIM) merupakan kegiatan manajemen yang dilakukan dengan memanfaatkan sistem informasi dalam penerapannya pada sebuah organisasi yang ditujukan untuk memberikan informasi - informasi yang diperlukan oleh organisasi tersebut. Pengembangan sistem informasi manajemen merupakan salah satu upaya yang dapat dilakukan untuk meningkatkan kualitas pelayanan publik, baik secara umum maupun pada sektor - sektor tertentu, misalnya pendidikan, terutama pada saat seperti ini (pandemi covid - 19), di mana kegiatan sosial masyarakat beralih menggunakan bantuan teknologi.

E - Layanan Fakultas Ilmu Pendidikan Unesa merupakan salah satu bentuk upaya peningkatan kualitas pelayanan publik di Fakultas Ilmu Pendidikan Unesa dengan memanfaatkan Sistem Informasi Manajemen (SIM). Setelah melalui beberapa tahap uji coba dan perbaikan hingga penyempurnaan, E - Layanan Fakultas Ilmu Pendidikan memperoleh hasil yang mendekati sempurna untuk digunakan. Penelitian ini menunjukkan hasil sebagai berikut: (1) pada tahap pengujian awal (Preliminary Field Testing) mendapatkan presentase hasil melebihi 30\% pada setiap kategorinya; (2) pada tahap pengujian yang kedua ditemukan beberapa hambatan tetapi dapat terselesaikan pada tahap selanjutnya; (3) pada tahap pengujian yang terakhir (Operational Product Testing) mendapat presentase hasil melebihi 70\% pada masing - masing kategorinya, ini berarti bahwa pengembangan E - Layanan sangat berguna. Dengan adanya $\mathrm{E}$ - Layanan juga aktivitas layanan akademik sangat terbantu terutama pada pasa pandemi Covid - 19 seperti saat ini. Hal ini juga berarti bahwa E - Layanan yang dikembangkan menggunakan Sistem Informasi Manajemen yang berbasis Codeigniter oleh Fakultas Ilmu Pendidikan Unesa sangat berguna dan layak untuk digunakan. 


\section{Saran}

Setiap implementasi suatu produk pasti ada kelebihan dan kekurangannya. Begitupun dalam pengembangan layanan pendidikan yang berbasis website ini. Beberapa kelemahan yang dimiliki E Layanan Fakultas Ilmu Pendidikan Unesa ini adalah masih bergantung pada provider internet dan wifi, juga sering disalah gunakan oleh pengguna yang tidak bertanggung jawab. Peneliti selanjutnya mungkin dapat memperbaiki kelemahan tersebut sehingga E - Layanan Fakultas Ilmu Pendidikan Unesa dapat berkembang lebih baik lagi.

\section{DAFTAR RUJUKAN}

Ahmad, La Ode Ismail dan Sinen, Ristati. 2017. "Penerapan Sistem Informasi Manajemen Pendidikan dakam Proses Pembelajaran di SMP Negeri 21 Makasar". JURNAL IDAARAH, Vol. I, No. 2, Hlm. 290-309.

Aldarbesti, Hassan dan Saxena, J. P. 2014. "Management Information System for Education". IOSR Journal of Research \& Method in Education (IOSR-JRME). Vol. 4, Issue 1, Ver. IV, Hlm. 36-44

Apriyansyah, Maullidina, Isnaini, Purnomo, Eko Priyo. 2018. "Efektivitas Sistem Informasi Desa (SID) Dalam Pelayanan Publik Di Desa Dlingo, Kecamatan Dlingo, Kabupaten Bantul”. Jurnal Analisis Kebijakan dan Pelayanan Publik. Vol. 4, No. 1, Hlm. 10-24

Berg, Bruce L \& Howard Lune. 2009. Qualitative Research Methods For The Social Science. Boston: Pearson.

Bright, Antwi Amankwah dan Asare, Gideon. 2019. "The Impact of Management Information Systemon University of Education Winneba, Kumasi Campus-Ghana". European Journal of Research and Reflection in Management Sciences. Vol. 7, No. 1, Hlm. 1-20.

Connolly, T., Begg, C. 2010. Database Systems: a practical approach to design, implementation, and management. 5th Edition. America: Pearson Education

Davis, G. B. 1993. Kerangka Dasar Sistem Informasi Manajemen. (Terjemahan Andreas S. Adiwardana). Jakarta: PT. Pustaka Binaman Pressindo.

Gall, M, D., Gall, J. P., \& Borg, W. R. 1983. Educational Research an Introduction; Third Edition. USA: Pearson Education.

Gall, Meredith D.Gall Joyce P. \& Borg, Walter R. 2003. Educational Research An Introduction, Seventh Edition. Boston: Pearson Education Inc.

Gushchin, Oksana dan Ochepovsky, Andrew. 2019. "Data Minning For The E - Learning Risk Management". Turkish Online Journal of Distance Education-TOJDE. Vol. 20, No.: 3 Article 13

Hall, James A. 2009. Sistem Informasi Akuntansi. Buku 2. Edisi Keempat (terjemahan). Jakarta: Salemba Empat.

Sagala, Syaiful. 2007. Konsep dan Makna Pembelajaran. Bandung: Alfabeta.

Sutabri, Tata. 2005. Sistem Informasi Manajemen. Yogyakarta: Andi.

Williams dan Sawyer. 2007. Using Information Technology terjemahan Indonesia. Penerbit ANDI.

Yuniko, Fauzi Tri dan Putra, Fitra Kusma. 2017. "Penerapan Teknologi Informasi Web Programing untuk Meningkatkan Pelayanan Publik dalam Bidang Kebijakan Administrasi Kependudukan". JOISIE Journal Of Information System And Informatics Engineering Vol. 1, No.1, Hlm 1-68 